\title{
Comedy of Socio-political Tragedies in Nigerian Popular Culture
}

\begin{abstract}
:
The intrinsic consequences of political actions on the society become more obvious in a developing state like Nigeria. Nigerians have consequently turned to comedy for relief as the country's comedy content is largely centred around ridiculing inefficiencies of the government. This study, therefore, attempted to ascertain the utility of comedy using insecurity as a paradigm. Three (3) politically-induced contemporary comedy shows on YouTube were analyzed using Sentiment Analysis in Nvivo and a search on "insecurity" and/or "security" was initiated. The analysis showed a predominance of neutral comments (53\%) indicating that most Nigerians remain unperturbed about their tragedies.
\end{abstract}

Keywords: Comedy; Socio-political Tragedy; Nigeria; Popular Culture

\section{Introduction}

Tragedies in Nigeria can be exemplified by the various prevalent social problems that cause both emotional and material distress in the country. Conceptualizing the word, Etzien (1980) argued that social problems are either 'societally induced conditions', such as poverty and unemployment, or the 'act and condition' that contradicts norms or standards of society (Adebisi et al., 2020); for instance, drug abuse by adolescents or youths, examination malpractices by students, vote-buying by politicians, and corruption by government officials among others. Social issues in the society are politically induced as most political problems have social consequences. According to social constructionists, conceptualizing social problems must begin as a process initiated by claim makers who raise concerns about some conditions that needed to be addressed. These concerns soon infiltrate a larger group (the general public, the media, policymakers, the social-problems workers) who then reconstruct such claims. In general, the process is complex: some issues lead to immediate responses from the larger community, while others find it difficult to reach an audience (Best, 2019).

Nigeria has witnessed an overwhelming amount of these tragedies both in earlier and recent times (Dark, 2017; Radda, 2010). Many of them have been reflected in the popular culture in both print and electronic media; ranging from newspaper articles and magazine pieces to feature-length films, television mini-series, shows, news, music, arts, documentaries, and even comic routines (Martin, 2011). Popular culture is usually associated with either mass culture or folk culture which are differentiated from high culture and various institutional cultures or systems (Kidd, 2017). Thus, the mass or folk culture could exist as a form of nonalignment or resistance to the high or institutional cultures and vice-versa. In Nigeria, the earliest claim makers like the late maverick Afrobeat musician, Fela Anikulapo-Kuti; Lemi Ghariokwu, the illustrator and designer; professor, and critic Chinua Achebe; Nobel Laureate, Wole Soyinka, have all raised concerns on many social conditions. Most of the time, these claims do not receive the claim makers' desired responses. 
For instance, with music; Fela Anikulapo-Kuti in his 1978 album, 'Shuffering and Shmiling', sang about 'societally induced conditions' and expressed his concern on how the Nigerian people have come to accept them. According to Afolayan (2013), Fela's Shuffering and Shmiling was presented in such a serious manner that it was expected to ignite a revolution, on the contrary, the Nigerian people, are complacent, only hoping that 'one day, e go better' (there will be a better deal in the hereafter). A study by Eesuola (2015) revealed that 'Shuffering and Shmiling' is a protest song that reflected the Nigerian tragedy with utmost seriousness, however, the song could only make Nigerians ponder on social problems but never to take any serious action. It appears that Nigerians are aware of their tragedies and they just want to be entertained by them.

Amongst the many social problems in the country, Insecurity is prevalent. Obarisiagbon \& Akintoye (2019) observed that insecurity in the country has recently assumed an alarming rate affecting every facet of Nigerian life with no end in sight. Despite this problem and others alike, Nigeria is ranked the $85^{\text {th }}$ happiest country in the world (Helliwell, Layard, \& Sachs, 2019). Nigerians always find a way to remain happy; they usually rely on comic relief from tragedies which are mostly reflected in popular culture, especially through comedy (Obadare, 2009; OsaeBrown, 2015). Rather than being bewildered by social problems, Nigerians could turn them into entertainment. According to Mendiburo-Seguel, Vargas, \& Rubio (2017), comedy could be grouped into two types; political and non-political. Although Nigerians joke about different social issues, one major theme in the country's comedy has to do with disparaging Nigerian politics, government, and its various consequences (Afolayan, 2013; Obadare, 2009). This is to say that the country's comedy is largely centered on ridiculing politics outflow from the corruption and insensitivity of the government. This could explain the rise of many content creators, who use comedy to address grievous political-related issues in the country. For instance, 'The Other News', 'Dr. Damages' and 'Keeping it Real' are all comic shows that comment on social and politicalrelated issues in Nigeria. Popular stand-up comedians in the country like 'Bovi, Ay, Basketmouth, and Gordons' among others have also presented similar issues with their comic performances.

\section{Problem Statement}

Within the overall context, studies that use comicality to approach the subject of social problems barely exist, despite an upsurge, constant and enormous productions from popular culture in the country. Nigerians love to be entertained amid their tragedies, consequently, they turn to comic relief (Osae-Brown, 2015). Essentially, comedy provides entertainment, however, its utility has evolved (Friedman, 2014). According to Adetunji (2013), comedy must serve the multiple functions of control and censure. Comedy also provides insights into the nature of people's relationships with other people and institutions. They are usually tailored to specific social experiences (Uwanamodo, 2019; Tavory, 2014). This approach to social problems, such as insecurity, is crucial because Nigerians love to be entertained and can, in effect, serve as a viable means of disseminating knowledge, particularly when institution sources, especially government or political ones, cannot be trusted because of experiences in the past or cause people more distress. The foregoing has over time led to a hoary inquiry over the utility of disparaging politics and the government in Nigeria. With the above in mind, it is therefore pertinent to gain a qualitative 
understanding of Insecurity as a politically-induced social problem in Nigeria and thus ascertain whether comedy is simply a comic-relief tool for Nigerians or can be a catalytic agent for social change.

\section{Method}

This article presents an analysis of three contemporary comedy shows on YouTube that focus on Political and social issues in Nigeria; "Dr. Damages", Keeping it Real" and "The Other News". For this study, a specific focus was placed on videos highlighting Nigeria's security challenges since President Buhari assumed power in 2015. On each channel, a search on "insecurity" and/or "security" was initiated, which returned a crop of videos. From this harvest of videos obtained, some videos that failed to address the issue of insecurity in line with this study were ignored. Thereafter, the search was narrowed down to 2 videos for each of the 3 Youtube channels. Two criteria were used as the basis of selection of these six (6) videos; reading the video title descriptions and thereafter checking for the most viewed videos on each channel. The most suitable and desirable videos were then viewed and summarised. Relevant comments (asides greetings and emojis) on the chosen videos were analyzed using the Sentiment Analysis technique available on Nvivo. The analysis examines the conduct of people (positive, negative, neutral, or mixed sentiments) on the political satire videos. Microsoft Excel was used to present the data in tables and charts.

\section{Theoretical Framework}

Zillmann in 1983 developed the Disparagement Humor (DH) model which refers to commentaries or narratives made amusingly to disparage, belittle, degrade or ridicule a given target; individuals, social groups, and political entities enabling the expression and satisfaction of belligerent impulses in a socially acceptable way (Ferguson \& Ford, 2008). The concept of DH is often strongly related to subjectivity or prejudice, given that the joke is not intended to be evaluated seriously. It is usually seen as burlesque; laughter for laughter's sake (The Other News CTV, 2017). When a target is disparaged, spectators are only likely to find it amusing and less likely to be critical of the content. Consequently, they might adopt the attitudes implicit in the message (Nabi, Moyer-Gusé, $\&$ Byrne, 2007). This could explain the unperturbed attitude of Nigerians to the revolutionary music, 'Shuffering and Shmiling', as submitted by Eesuola (2015). This principle can also be applied to the political terrain, considering that when a political administration is disparaged, the administered will be in a good disposition to accept the negative descriptions attributed to such polity (Mendiburo-Seguel, Vargas, \& Rubio, 2017).

Although DH has its roots in psychoanalytic theories, it can and has been analyzed within social identity theory (Tajfel \& Billig, 1974). Inferred from Uwanamodo's (2019) argument, this becomes possible as comedy categorizes people with similar experiences into a group while the disparaged entity automatically falls into the other group thereby creating a "we" and "them" situation. People construct their social identity, morale, and cohesion through the comparison and positive distinctiveness of the groups they belong to; in-groups, with the out-groups to 'sustain the morale and cohesion of groups (Mendiburo-Seguel et al., 2017; Tavory, 2014; Fine, 1984). DH can, 
therefore, be used as a way to obtain a separate positive identity, especially when the out-group has been linked with some negativity.

In this context, both the comedian and the spectators assume the in-group identity, while the government and politicians are seen as the out-group as theorized by the disposition theory of humor and mirth which postulated that; the more intense the negative disposition toward a disparaged agent (in this case, the politicians), the greater the magnitude of humor; the more intense the positive disposition toward the disparaged agent, the smaller the magnitude of humor; and the more intense the negative disposition toward the disparaging agent (comedian), the smaller the magnitude of humor (Zillmann \& Cantor, 1972, 1976).

The burlesque element of DH suggests that comedy is neither harmless to the disparaged entity nor does it call for social change. It is simply humor for laughter's sake. This negates an aspect of Bergson's (1911) theory of humor, where humor does not only serve as means of escaping the rigors of the social world (Obadare, 2009) but could serve as a tool for control, censure, and/or change simply by comparing a target with a socially accepted negativity (for instance, a deviant) (Adetunji, 2013; Cameron, 1993). Going further, disparaging an entity may be intended for amusement only, however, from the theory of manifest and latent functions, unintended functions cannot be overlooked. Robert K. Merton in his 1949 book 'Social Theory and Social Structure' argued that latent functions are neither conscious nor deliberate but also produce benefits.

\section{Comedy Transition in Nigeria}

Comedy exists in all established world cultures and is as old as society itself (Gbinije 2005; Taiwo, 2017). In Nigeria, comedy has thrived so much that it has metamorphosed into the third biggest entertainment industry, after 'Nollywood' and music (Osae-Brown, 2015). According to Taiwo (2017), the history of Nigerian comedy can be essentially grouped into three categories, focusing on the comedians. They include the pioneer class, the second, and third generations.

The pioneer class represents the earliest crops of comedians, particularly in pre-colonial and colonial Nigeria. This character involves village spoke-persons found to be very hilarious. They are often invited to infuse humor into village social events. Names that readily comes to bare includes; Sunday Omobolanle (PapiLuwe/Aluwe), Ayo Ogunshina (Papa Lolo), Moses Olaiya (Baba Sala), Usman Baba Pategi (Samanja), James Iroha (Gringory), Afolabi Afolayan (Jagua), Chika Okpala (Zebrudaya), Kayode Olaiya (Aderupoko), and Tajudeen Gbadamosi (Jacob) among others (Ijalana, 2010; Olonilua, 2011; Dede, 2014; Haynes, 1994; Ezebuiro, 1994).

This generation of comedians continued until the 1990s. They engaged mostly in theater comedy and there was a little financial reward for their comic performances. It became necessary for most of them to engage in other vocations such as playing host to a variety of events, including political campaigns; a situation that will later usher in stand-up comedy. Although these personalities were applauded for providing the much needed comic relief and distraction from serious daily endeavors and tragedies, their comic characters also constituted metaphors for reprimanding deviant behaviors in society. This aligns with an aspect of Bergson's theory of humor, where humor is considered to be a tool for restoring the deviant simply by mocking their peculiarities (Cameron, 
1993). During this era, even though comedy had both tendencies to serve as relief from social problems, and a tool for social change, the target was not necessarily politics.

The second-generation comedians surpassed the previous generation in terms of numbers. They include personalities such as Babatunde Omidina (Baba Suwe), Sam Loco Efe, Mazi Mpeperempe, Gbenga Adeboye (Mr. Funwantan), Atunyota Akpobome (Ali Baba), Francis Agoda (I Go Die), Julius Agwu, Nkem Owoh (Osofia), Bolaji Amusan (Mr. Latin), Okechukwu Onyegbule (Okey Bakassi), Bright Okpocha (Basket Mouth), Ayo Makun (AY), Godwin Komone (Gordons) among many others.

This generation is a fusion of both theatre comedy and stand-up comedy, however, stand-up comedy had already become a mainstream genre by 1993. Comedians were purposely allowed to regale the public in the expectation that their performance would inject a casual slant to otherwise serious programs. This gave birth to popular television talks-shows like the 'Charly Boy Show, Friday Night Life, and Night Train', among others (Adetunji, 2013). In 1995, the first edition of Night of a Thousand Laugh, a dedicated live event strictly involving only stand-up comedy was witnessed. Several comedians have since then hosted their comedy shows. Some of them include AY Live, Basket Mouth Uncensored, Lord of the Ribs, and many more. It is worth mentioning that the content of the performance of the second-generation comic culture has a variety of targets. Ridicule or disparagement is a significant theme in this era (Olonilua, 2011).

The third-generation boast of prominent personalities considered to have been mentored by the preceding generation. They include; Seyi Law, Omo Baba, Gondoki, I Go Save, Aboki4Christ, Princess, Lolo, Lepacious Bose, Helen Paul, and Akpororo among others. With the influence of the internet, this genre of comedy emerged, and by consequence, the third generation comedians (and second-generation comedians who want to remain relevant) have to move most of their activities online.

This generation led to another generation, an emerging-generation or a fourth. This fourth generation is unique in that it accommodates almost every Nigerian who has an online presence with regular comic activities. For instance, a young girl called Emmanuela, became very popular for uploading comedy skits online. Internet comedy has become a familiar genre in the country probably because of its independence, originality, and simplicity. Many Nigerians have become ad hoc or full-time comedians as a result. Names that readily comes to bare are; Samuel Perry (Broda Shaggi), Michael Sani Amanesi (Barrister Mike), Ereme Abraham (Twyse Ereme), Chinedu Ani Emmanuel (Nedu), Oluwatoyin Bayegun (Wole Arole), Ayo Ajewole (Wole Agba), Gloria Oloruntobi (Maraji), Nosa Afolabi (Lasisi Elenu), Debo Adedayo (Mr. Macaroni), Egere Sydney (Sydney talker), MC Tagwaye (Obinna Simon), among many others.

\section{Insecurity as a Tragedy in Nigeria (2015-2019)}

After enduring several decades of maladministration, the Nigerian electorate got tired of the pervasive leadership bankruptcy of its ruling elites and decided to give Buhari a shot at Aso Villa by electing him as the Fourth President of the Nigerian Fourth Republic. Buhari assumed the office 
of the presidency at one of the most difficult times in Nigeria's history with his pre-election campaign promises standing on a tripod stance of Economic development, tackling Corruption, and ending Insecurity (Welsh, 2015; Dembele, 2016). The 2015 general election in Nigeria brought about a new dimension into Nigerian politics as it was the first time that an opposition party would defeat the ruling party at the polls (Olowojolu, 2017). However, four years down the line, Nigerians cannot but ask pertinent questions as to the state of the nation in line with promises made during the presidential campaigns.

Supporters of President Buhari are keen to espouse all the steps taken by his government in these 3 key areas in proving his forthrightness. Specifically, on security, Buhari visited Niger Republic, Cameroon, Benin Republic, Chad, G-7 meeting in Berlin and the United States few days after assuming office as President and also ordered the relocation of military command to Maiduguri, a step aimed at taking the fight against terrorism closer to the epicenter of the Boko Haram insurgency. Buhari also championed the creation of the Multinational Joint Task Force (MNJTF), which is composed of 8,700 standing army officers pulled from member countries of the Lake Chad Basin Commission (Vanguard, 2015). Similarly, 103 out of the 276 Chibok girls that were kidnapped by Boko Haram on April 14, 2014, have been released. The release of the kidnapped girls was done with the help of the Swiss government, the International Red Cross, and the Nigerian government (Vanguard, 2017).

The success or otherwise of Buhari administration efforts can only be correctly accessed when the promises made during the electioneering period is compared with the prevailing situation on ground over 4 years after assumption of office. Nigerians know better, as they feel the impact of the performance or otherwise of the administration when juxtaposed with the campaign promises. While it can be agreed that the MNJTF coupled with the Civilian Joint Task Force yielded some early positive results in the fight against terrorism coupled with the release of 103 out of the 276 kidnapped Chibok girls, the abduction of over 100 girls by BokoHaram from Government Girls Science School in Dapchi, Yobe State completely erased any gains recorded thus far by this administration in this area. Nigerians were confused as to how a 'defeated' Boko Haram can drive its convoy of vehicles into the town of Dapchi and abduct so many of our girls and drive away without any resistance from our security forces.

Asides the Boko Haram insurgency, another security challenge that has worsened under the Buhari administration is the deadly Fulani herdsmen attacks that have continued to terrorize several parts of the country, killing harmless farmers, destroying farmlands, sacking villages and rendering many homeless while the government seems not ready to take any concrete steps to stop these tragedies. The North-western region is not spared either from the pervasive insecurity currently besetting Nigeria with armed bandits who invade villages, leaving scores of people dead and homes destroyed. In other parts of the country, kidnapping for ransom has become like a normal trade, particularly in the South-south, southeast, and southwest. Ritual killings have also spiked in many towns as Nigerians feel quite unsafe in a country where the government seems to have failed in its primary responsibility of protecting the lives and properties of its citizens. 


\section{Analysis}

The 3 contemporary comedy shows under study are 'Dr. Damages', 'Keeping it Real', and 'The Other News'. Comments on each show were analyzed using sentiment analysis.

Dr. Damages, with real names Rudolf Okonkwo is a political satirist and a veteran of the Nigerian media. Before leaving Nigeria for the United States where he has since been based, he wrote for Classic Magazine and Nigeria Daily Mail newspaper. Dr. Damages believes in "holding people in authority accountable" and has been airing his show weekly since 2011 (Dr. Damages, n.d.).

Video 1: 'RUGA, Shiite, etc. VP Osinbajo as Buhari's enabler

Synopsis: This video posted on July 31, 2019 comments on varying issues such as the failure of the government of President Buhari to deal with insecurity in Nigeria as it relates to the herdsmen and farmers' conflicts that have resulted in deaths of several Nigerians. The video criticized the "RUGA" solution proffered by the Presidential Committee. The video ended by criticizing Vice President Yemi Osinbajo for keeping quiet as a Law Professor while extra-judicial killings by Nigerian security forces and disobedience of court orders take place. (Dr. Damages, 2015, 15:51)

Table 1: Tabular representation showing Viewers' Sentiments of Video 1

\begin{tabular}{|l|c|c|c|}
\hline \multicolumn{1}{|c|}{ Nodes } & $\begin{array}{c}\text { Number of coding } \\
\text { references }\end{array}$ & Percentage & $\begin{array}{c}\text { Number of items } \\
\text { coded }\end{array}$ \\
\hline Total Analysed Comments & 214 & $100 \%$ & 1 \\
\hline Positive & 40 & $19 \%$ & 1 \\
\hline Negative & 29 & $14 \%$ & 1 \\
\hline Mixed & 4 & $2 \%$ & 1 \\
\hline Neutral & 141 & $66 \%$ & 1 \\
\hline
\end{tabular}

Source: Authors' Compilation, 2020

Figure 1: Sentiment Chart of Video 1

Ruga, Shite etc;VP Osinbajo as Buhari's enabler

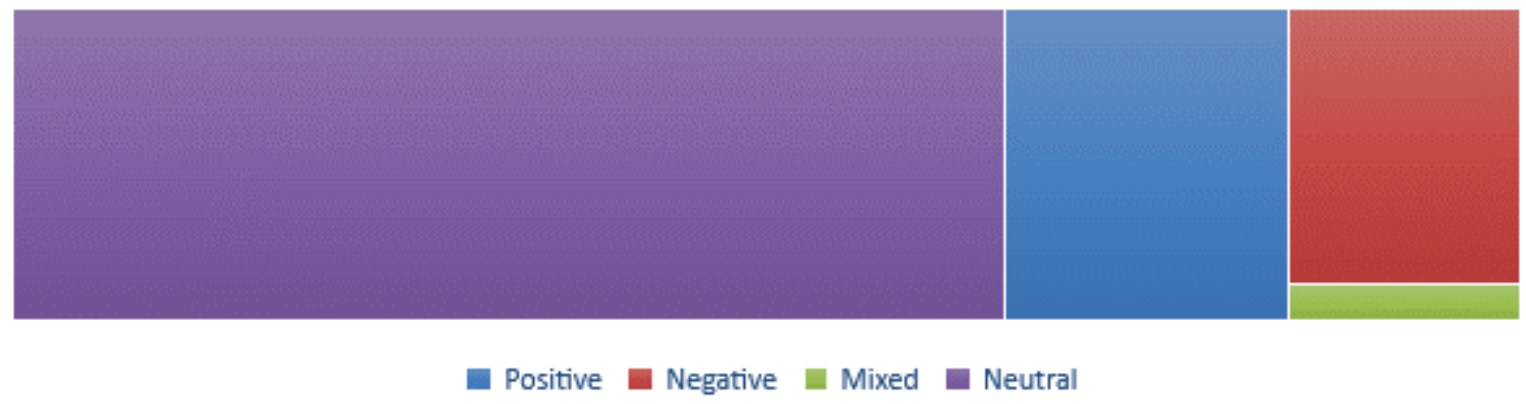

Source: Authors' Compilation, 2020

Video 2: 'With Buhari it is incompetence in bed with incompetence'

Synopsis: 
This video posted Feb 7, 2020 speaks to the perceived competency of the Nigerian government of President Buhari to end the scourge of insecurity in the country. The video expressed shock that despite the poor performance of the various security agencies in the country as seen in the pervasive insecurity being experienced in the country, the Service Chiefs of the Nigerian Army, Navy and the Air Force are still in Office even though they have also all put in the mandatory 35 years in service and should have been retired (Dr. Damages, 2020, 0:54)

Table 2: Tabular representation showing Viewers' Sentiments of Video 2

\begin{tabular}{|l|c|c|c|}
\hline \multicolumn{1}{|c|}{ Nodes } & $\begin{array}{c}\text { Number of coding } \\
\text { references }\end{array}$ & Percentage & $\begin{array}{c}\text { Number of items } \\
\text { coded }\end{array}$ \\
\hline Total Analysed Comments & 67 & $100 \%$ & 1 \\
\hline Positive & 4 & $6 \%$ & 1 \\
\hline Negative & 19 & $19 \%$ & 1 \\
\hline Mixed & 5 & $7 \%$ & 1 \\
\hline Neutral & 39 & $58 \%$ & 1 \\
\hline
\end{tabular}

Source: Authors' Compilation, 2020

Figure 2: Sentiment Chart of Video 2

With Buhari it is Incompetence in bed with Incompetence

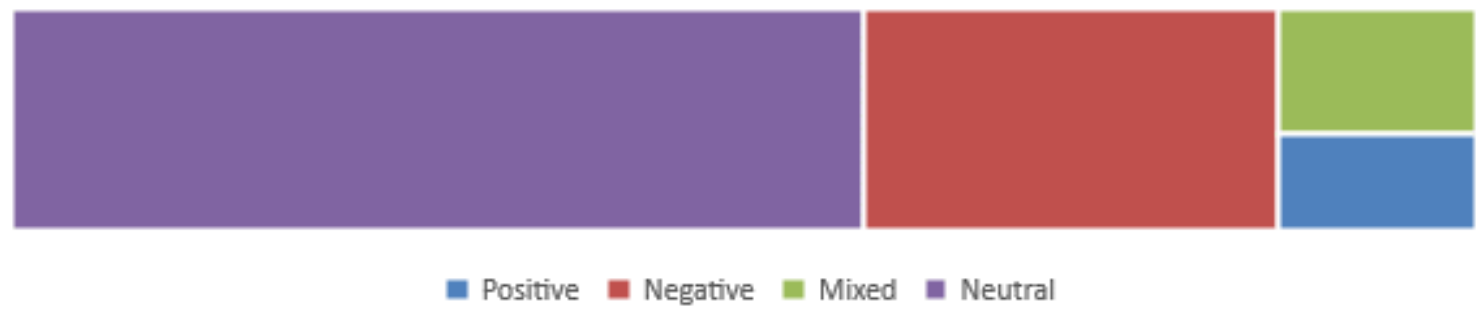

Source: Authors' Compilation, 2020

"Keeping it Real" is hosted by Adeola Fayehun, a Nigerian satirist and journalist who specializes in discussing current geopolitical, social, and economic issues that affect the daily lives of Africans living on the continent (Adeola Fayehun, n.d.).

Video 3: 'Security: Buhari Has Failed...'

Synopsis:

This video posted Feb 7, 2020 speaks to the perceived competency of the Nigerian government of President Buhari to end the scourge of insecurity in the country. According to the video, the government has failed especially when it comes to security as kidnapping, banditry and ritual (Adeola Fayehun, 2019, 2:33)

Table 3: Tabular representation showing Viewers' Sentiments of Video 3

\begin{tabular}{|c|c|c|c|}
\hline Nodes & $\begin{array}{c}\text { Number of coding } \\
\text { references }\end{array}$ & Percentage & $\begin{array}{c}\text { Number of items } \\
\text { coded }\end{array}$ \\
\hline
\end{tabular}




\begin{tabular}{|l|c|c|c|}
\cline { 3 - 3 } Total Analysed Comments & 569 & $100 \%$ & 1 \\
\hline Positive & 34 & $6 \%$ & 1 \\
\hline Negative & 187 & $33 \%$ & 1 \\
\hline Mixed & 70 & $12 \%$ & 1 \\
\hline Neutral & 278 & $49 \%$ & 1 \\
\hline
\end{tabular}

Source: Authors' Compilation, 2020

Figure 3: Sentiment Chart of Video 3

Security: Buhari has failed

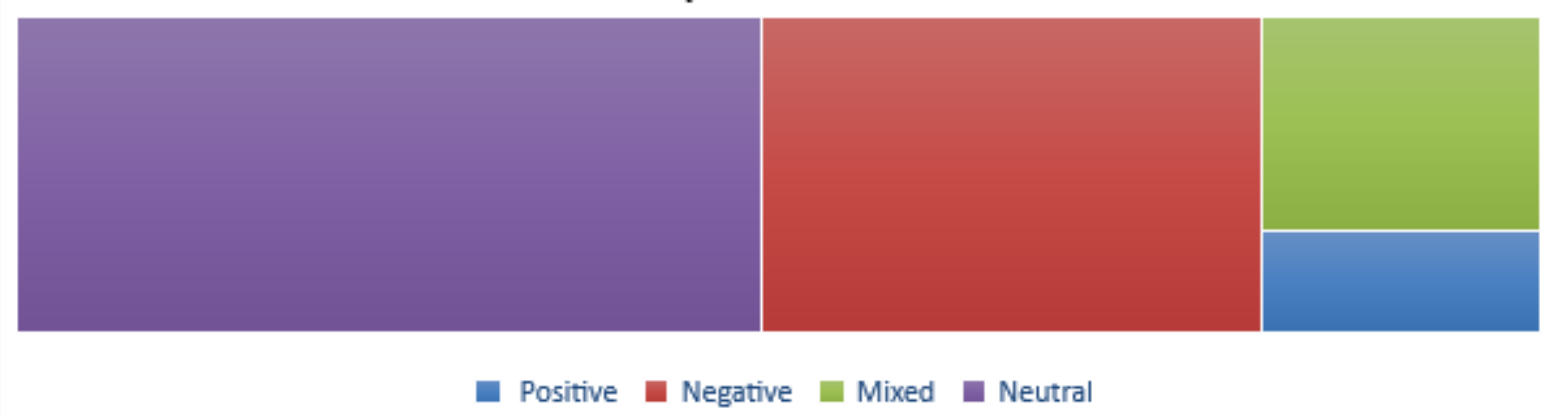

Source: Authors' Compilation, 2020

Video 4: 'Amotekun vs. Buhari...'

Synopsis:

This video posted January 21, 2020 speaks to the newly inaugurated South-West Security Network codenamed Operation Amotekun. It is a security outfit launched by the six (6) states of the South Western, Nigeria as a response to the perceived failure of the federal government-owned security architecture of the country. According to the video, Operation 'Amotekun' came as a result of the failure of the federal government to ensure the safety in the security of its people and wondered why the federal government of Nigeria led by President Buhari was against this set-up (Adeola Fayehun, 2019, 0:59)

Table 4: Tabular representation showing Viewers' Sentiments of Video 4

\begin{tabular}{|l|c|c|c|}
\hline \multicolumn{1}{|c|}{ Nodes } & $\begin{array}{c}\text { Number of coding } \\
\text { references }\end{array}$ & Percentage & $\begin{array}{c}\text { Number of items } \\
\text { coded }\end{array}$ \\
\hline Total Analysed Comments & 533 & $100 \%$ & 1 \\
\hline Positive & 37 & $7 \%$ & 1 \\
\hline Negative & 165 & $31 \%$ & 1 \\
\hline Mixed & 66 & $12 \%$ & 1 \\
\hline Neutral & 265 & $50 \%$ & 1 \\
\hline
\end{tabular}

Source: Authors' Compilation, 2020

Figure 4: Sentiment Analysis of Video 4 


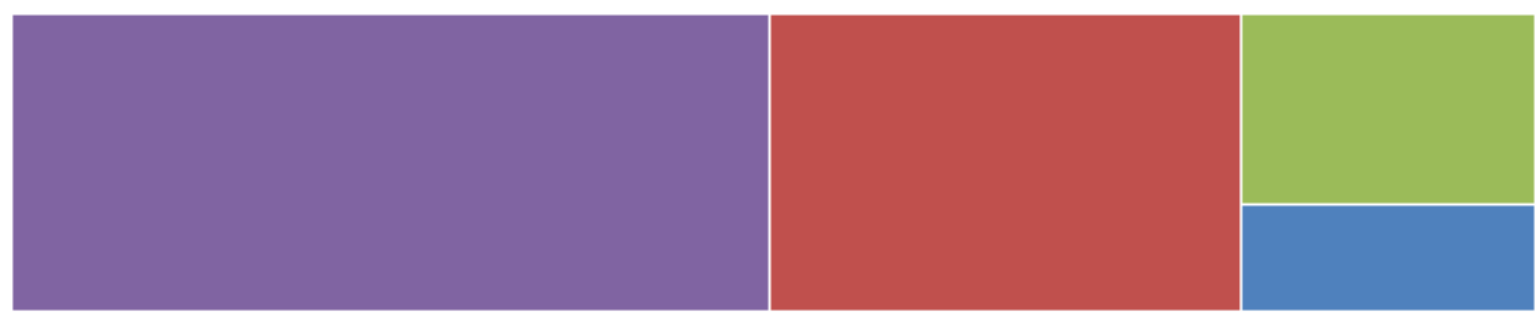

Source: Authors' Compilation, 2020

C. The Other News is a Political Satire TV Show that takes a reality-based look at news, trends, politics, breaking events, etc. with another angle from seriousness hosted by Okechukwu Anthony Onyegbule also known as Okey Bakassi. The show which records remote pieces and guests in the studio discusses important news happenings with a lighter side to it (The Other News CTV, n.d.).

Video 5: 'Boko Haram Returns Dapchi Girls...'

Synopsis:

This video posted March 23, 2018 comments on the celebration of the return of the abducted schoolgirls in the northeastern town of Dapchi, Bauchi State. The schoolgirls were earlier abducted by the Boko Haram terrorist group amidst the insecurity in the North-east region of Nigeria (The Other News CTV, 2018, 0:01)

Table 5: Tabular representation showing Viewers' Sentiments of Video 5

\begin{tabular}{|l|c|c|c|}
\hline \multicolumn{1}{|c|}{ Nodes } & $\begin{array}{c}\text { Number of coding } \\
\text { references }\end{array}$ & Percentage & $\begin{array}{c}\text { Number of items } \\
\text { coded }\end{array}$ \\
\hline Total Analysed Comments & 7 & $100 \%$ & 1 \\
\hline Positive & 0 & $0 \%$ & 0 \\
\hline Negative & 0 & $0 \%$ & 0 \\
\hline Mixed & 0 & $0 \%$ & 0 \\
\hline Neutral & 7 & $100 \%$ & 1 \\
\hline
\end{tabular}

Source: Authors' Compilation, 2020

Figure 5: Sentiment Chart of Video 5 


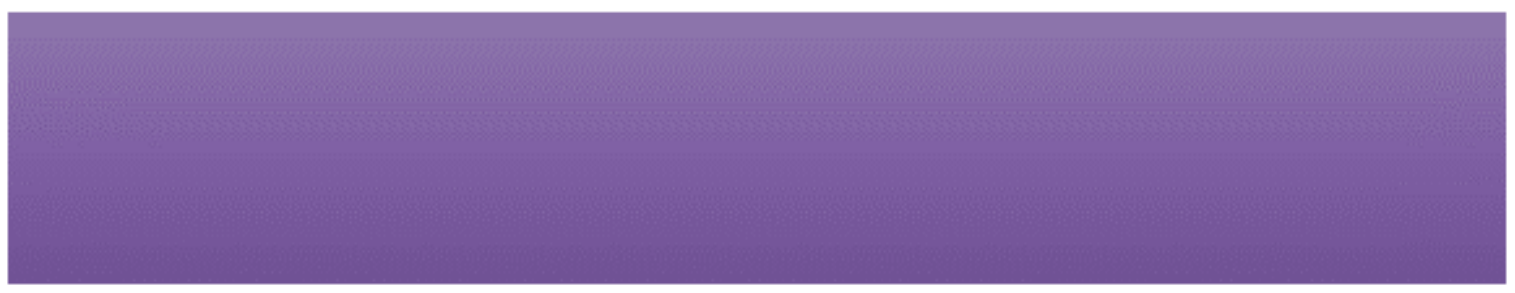

Positive Negative $\square$ Mixed Neutral

Source: Authors' Compilation, 2020

Video 6: 'I Am Tired Says Boko Haram Leader Shekau'

Synopsis:

This video posted February 15, 2018, speaks about the fight against terrorism in the North-east of Nigeria (The Other News CTV, 2018, 0:29)

Table 6: Tabular representation showing Viewers' Sentiments of Video 6

\begin{tabular}{|l|c|c|c|}
\hline \multicolumn{1}{|c|}{ Nodes } & $\begin{array}{c}\text { Number of coding } \\
\text { references }\end{array}$ & Percentage & $\begin{array}{c}\text { Number of items } \\
\text { coded }\end{array}$ \\
\hline Total Analysed Comments & 9 & $100 \%$ & 1 \\
\hline Positive & 0 & 0 & 0 \\
\hline Negative & 0 & 0 & 0 \\
\hline Mixed & 0 & 0 & 0 \\
\hline Neutral & 9 & $100 \%$ & 1 \\
\hline
\end{tabular}

Source: Authors' Compilation, 2020

Figure 6: Sentiment Chart of Video 6

I am tired says Boko Haram Leader Shekau

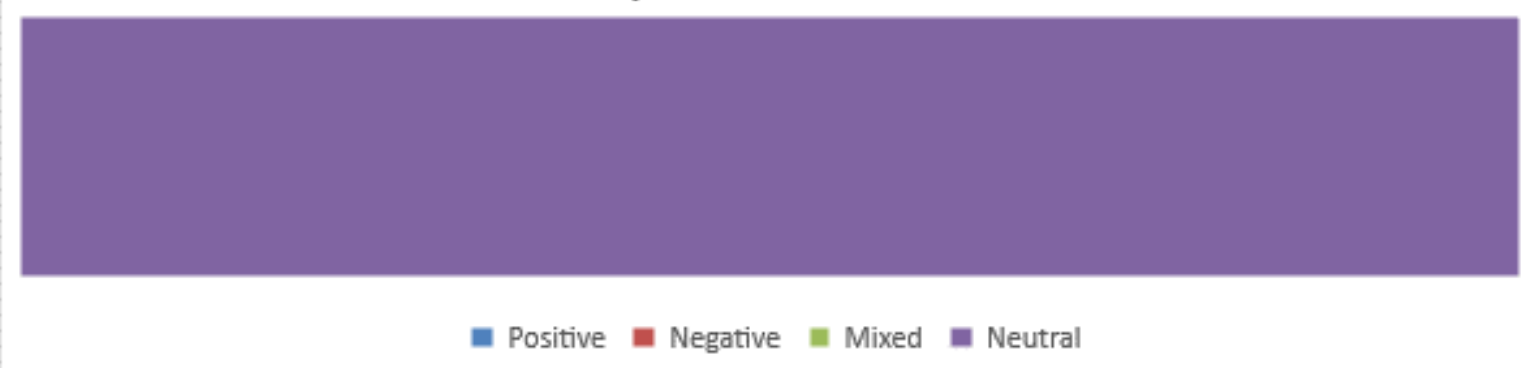

Source: Authors' Compilation, 2020

\section{Discussion:}


Sentiment analysis evaluates the actions of a speaker or author about a specific subject or the conceptual polarity of a document as a whole (Jagdale et al., 2016; Mittal \& Patidar, 2019). The analysis deals with detecting polarity rather than discrete emotions, which could be measured as positive, negative, neutral or mixed (Chaturvedi et al., 2018; Bae \& Lee, 2012; Koppel \& Schler, 2006), and they are adjudged based on specific words or phrase mentioned by the author or writer For instance; 'happy, confidence, excellent' are regarded as positive sentiments, while 'bad, failure, sadness are regarded negative (HaCohen-Kerner \& Badash, 2016; Alexander Pak, 2016). Neutral sentiments express no opinion on the subject matter (Zhang et al., 2011). They contain words or phrases like view, baby, quick, touch, etc (Chaturvedi et al., 2018). Mixed sentiments allow for complex linguistic constructions. patterns like both excited and anxious or neither happy nor sad represent a challenge for automatic sentiment analysis systems (Dzogang et al., 2010), thus, the mixed sentiment is adopted.

Table 7 and Figure 7 below presents the sum of the Sentiment Analysis of the comments used in this study.

Table 7: Tabular representation showing Viewers' Sentiments of All Videos

\begin{tabular}{|l|c|c|c|}
\hline \multicolumn{1}{|c|}{ Nodes } & $\begin{array}{c}\text { Number of coding } \\
\text { references }\end{array}$ & Percentage & $\begin{array}{c}\text { Number of } \\
\text { items coded }\end{array}$ \\
\hline Total Analysed Comments & 1399 & $100 \%$ & 6 \\
\hline Total Positive Comments & 115 & $8 \%$ & 6 \\
\hline Total Negative Comments & 400 & $29 \%$ & 4 \\
\hline Total Mixed Comments & 145 & $10 \%$ & 4 \\
\hline Total Neutral Comments & 739 & $53 \%$ & 6 \\
\hline
\end{tabular}

Figure 7: Sentiment Chart of Video 7

\section{Total Sentiment Analysis Chart}

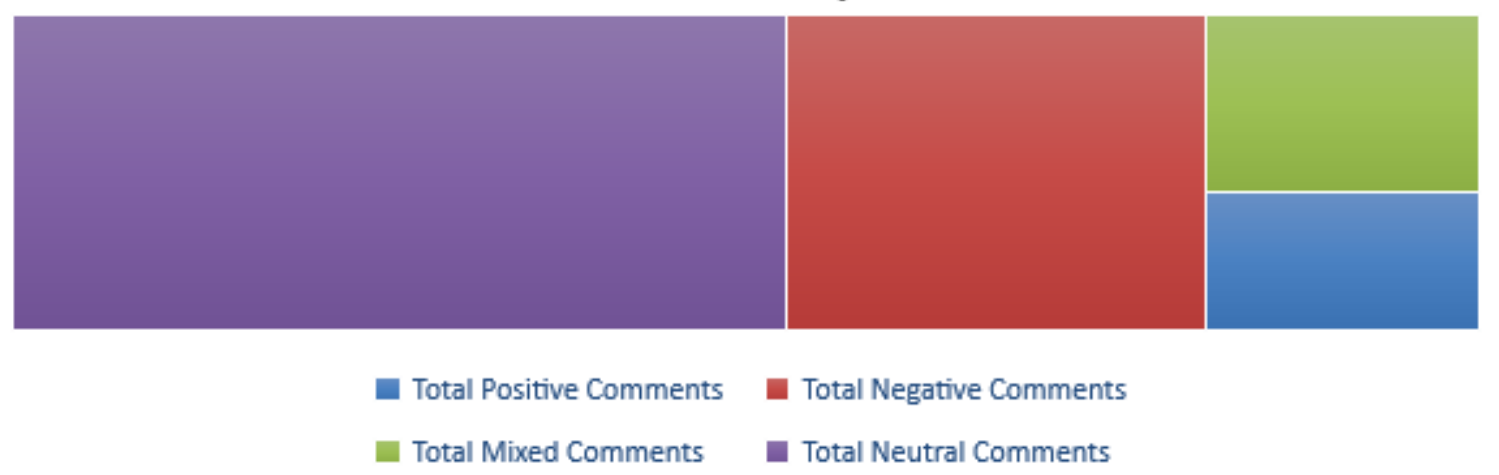

Source: Authors' Compilation, 2020

Of the total 1,399 analyzed comments, $53 \%$ are neutral, $8 \%$ positive $29 \%$ negative, and $10 \%$ mixed. The analysis of the sentiments showed that in all reactions to the videos, the majority 
showed no sentiment (neutral). However, within the category of those who showed sentiments, the highest percentage were negative sentiments which was significantly higher than that of positive sentiments (see Fig. 7), confirming previous studies that Nigerians remain unperturbed about their many tragedies (Eesuola, 2015) since neutrality has been interpreted as no sentiments (Zhang et al., 2011). Although the negative sentiment is relatively lower than neutral at $29 \%$, yet it has the highest count that conveys messages of dissatisfaction with the country's security challenge. Table 8 as highlighted below depicts the negative word counts derived from the comments. Words such as "corruption", "protests", "poverty", "useless", "failure", etc came out prominent only second the neutral comments.

Table 8: Showing the Negative sentiments from Videos 1-4

\begin{tabular}{|c|c|c|c|}
\hline A : Very negative & $\begin{array}{c}\text { B : Moderately } \\
\text { negative }\end{array}$ & $\begin{array}{c}\text { C : Moderately } \\
\text { positive }\end{array}$ & D : Very positive \\
\hline 4374 & 3573 & 2871 & 2211 \\
\hline 345 & 295 & 532 & 188 \\
\hline 5148 & 3420 & 3114 & 1958 \\
\hline 683 & 447 & 765 & 50 \\
\hline
\end{tabular}

Furthermore, $10 \%$ of the total sentiments account for mixed sentiments, meaning that this category of viewers who commented on the videos expressed both positive and negative sentiments. Positive sentiment is extremely low at $8 \%$. It can be concluded comedy in Nigeria is best at its manifest function of comic-relief and not a tool for social change.

\section{Conclusion}

Nigerian has enormous claim makers who raise concerns about harsh social conditions induced by political and policy decisions and demands urgent attention. For social change to occur, particularly in the aspect of insecurity in Nigeria, it will take more than conceptualizing and commentating on the social problem. Nigerians are generally resilient in nature and they often boast in their ability to survive severe social conditions. As confirmed by this study, it is obvious that the population of the unperturbed (neutral) is significantly greater than that of the disturbed (negative sentiment). This will inevitably contribute to the maintenance of the status quo, thereby allowing for continuous negligence of the government and its agencies from their constitutional responsibilities of providing adequate security of lives and properties.

A very vital area requiring further research arising from the outcome of this study is an investigation into viable reasons that accounts for the complacency and nonchalance of Nigerians regarding their present tragedy as seen in their socio-political conditions characterized by abject poverty, pervasive insecurity, massive public corruption, etc. Furthermore, it is pertinent to probe into other factors asides conceptualizing and commentating on social problems that could instigate social change in Nigeria thereby placing a demand of responsibility on the country's political leaders. 


\section{References}

Adebisi, T., Alabi, O., Arisukwu, O., \& Asamu, F. (2020). Gambling in Transition: Assessing Youth Narratives of Gambling in Nigeria. Journal of Gambling Studies, 0123456789. https://doi.org/10.1007/s10899-020-09982-X

Adeola Fayehun. (n.d.). (955) Adeola Fayehun - YouTube. Retrieved May 22, 2020, from https://www.youtube.com/user/AdeolaFayehun/about

Adeola Fayehun. (2019, May 16). Buhari to Fight Insecurity With CCTV; Dino for Gov.; Smelly Fart at Kenyan Debate, Liberian Airport [Video file]. YouTube. https://youtu.be/91h1TjMwUmE

Adeola Fayehun. (2019, May 16). Security: Buhari Has Failed; Faure To Rule Till 2030; Get Schengen Visa; Caster Semenya; Lagos New $B$ [Video file]. YouTube. https://youtu.be/mPj7vnWIGRw

Adeola Fayehun. (2020, January 21). Amotekun vs. Buhari; Africa's Richest Woman To Run For Office; Liberia's George Weah; Gambia; Kenya [Video file]. YouTube. https://youtu.be/CQbQGnBM33M

Adetunji, A. (2013). 'The Interactional Content of Humour in Nigerian Stand-Up Comedy. Pragmatics. 23: 3.

Afolayan, A. (2013). Hilarity and the Nigerian Condition. The Journal of Pan African Studies, 6(5), 10297. Retrieved from http://jpanafrican.org/docs/vol6no5/6.5-Afolayan.pdf

Alexander Pak, P. P. (2016). Twitter as a Corpus for Sentiment Analysis and Opinion Mining. IJARCCE, 5(12), 320-322. https://doi.org/10.17148/IJARCCE.2016.51274

Bala, M. (2010) "The Contributions of Hisbah in Curbing Social Problems in Kano Metropolis" An M.Sc Dissertation Submitted to the Department of Sociology, Bayero University, Kano, Nigeria.

Bae, Y., \& Lee, H. (2012). Sentiment analysis of twitter audiences: Measuring the positive or negative influence of popular twitterers. Journal of the American Society for Information Science and Technology, 63(12), 2521-2535. https://doi.org/10.1002/asi.22768

Bergson, H. (1911) Laughter: An Essay on the Meaning of the Comic. Trans. Cloudesten Brereton and Fred Rothwell. New York: Macmillan. [Le rire, 1900.]

Best, J. (2019). Social Problems. obo in Sociology. doi: 10.1093/obo/9780199756384-0052

Billig, M. (2005). Laughter and Ridicule. Towards a Social Critique of Humour. London: Sage Publications. 38-39, 83, 110-131

Bovi in Bovi Man on Fire 2013, Flytime Promotion, Lagos.

Cameron, Kieth. (1993). 'Humour in History', Humour and History, edited by Kieth Cameron. London: Intellect Books. 5-14.

Chaturvedi, I., Cambria, E., Welsch, R. E., \& Herrera, F. (2018). Distinguishing between facts and 
opinions for sentiment analysis: Survey and challenges. Information Fusion, 44(December 2017), 65-77. https://doi.org/10.1016/j.inffus.2017.12.006

Dark, S., (2017). Nigerians Are Making Fun Of Their Leaders, But To What End? - African Arguments. [online] African Arguments. Available at: $<$ https://africanarguments.org/2017/12/06/nigeria-satire-are-making-fun-of-their-leaderswhat-end/> [Accessed 19 March 2020].

Dede, S. (2014). 'Nigeria's Pioneer Comedians, Gbenga “Funwotan" Adeboye'. NetNewspapers. Viewed on 29 April 2016.www.thenet.com

Dembele, Y. (2016). Appraising the Buhari administration: The Middle Belt and missteps on the promise of neutrality. Open Doors International/World Watch Research Unit www.opendoorsanalytical.org

Dr. Damages. (n.d.). (955) Dr. Damages - YouTube. Retrieved May 22, 2020, from https://www.youtube.com/channel/UCiMj68yvBuTO9aDF1FjyobA/about

Dr. Damages. (2020, February 7). With Buhari it is incompetence in bed with incompetence [Video]. YouTube. https://youtu.be/LEiKe31_Lsw

Dr. Damages. (2019, August 15). Dr. Damages Show episode 385: RUGA, Shiite etc: VP Osinbajo as Buhari's enabler [Video]. YouTube. https://youtu.be/r7h3OCgBa50

Dr. Damages. (2019, February 7). Dr. Damages Show - episode 387: DSS arrests Sowore, Kenya deports Jesus [Video]. YouTube. https://youtu.be/RDIw3EkeraY

Dzogang, F., Lesot, M.-J., Rifqi, M., \& Bouchon-Meunier, B. (2010). Expressions of graduality for sentiments analysis \&\#x2014; A survey. International Conference on Fuzzy Systems, 17. https://doi.org/10.1109/FUZZY.2010.5584148

Eesuola, O. S. (2015). Political Protest Songs and Actual Protest Values: Analysis of Fela's "Sorrow, Tears \& Blood" and Bob Marley's "Stand up, Get up." International Journal of Arts and Humanities, 4(2), 82-96. https://doi.org/10.4314/ijah.v4i2.7

Eezebuiro, P. (2015). 'Nigeria's Comedy. Fore-fathers We Cannot Forget Too Soon'. Viewed on 29 April 2016. http://www.buzznigeria.com

Etzien, D. and Stanley, (1980). Social Problems. Boston, Allyn Bacon, INC.

Ferguson, M. A., \& Ford, T. E. (2008). Disparagement humor: A theoretical and empirical review of psychoanalytic, superiority, and social identity theories. Humor, 21(3), 283-312. https://doi.org/10.1515/HUMOR.2008.014

Fine, G. A. (1984). Humorous interaction and the social construction of meaning: Making sense in a jocular vein. Studies in Symbolic Interaction, 5, 83-101.

Flytime Promotions. (2014, September 10). BOVI MAN ON FIRE 2013 "PRESIDENTIAL SPEECH" [Video file]. Retrieved from https://youtu.be/fH9bf4P8R28

Friedman, S. (2014). Comedy and distinction: The cultural currency of a 'good' sense of humour. Comedy and Distinction: The Cultural Currency of a "good" Sense of Humour, 1- 
228. https://doi.org/10.4324/9780203740279

Gbinije, B. (2013). 'Comedy, Comedians and Nigeria's rebirth'. Vanguard. Viewed 29 April 2016, http://www.vanguardngr.com

HaCohen-Kerner, Y., \& Badash, H. (2016). Positive and Negative Sentiment Words in a Blog Corpus Written in Hebrew. Procedia Computer Science, 96, 733-743. https://doi.org/10.1016/j.procs.2016.08.257

Haynes, J. (1994). Structural Adjustment of Nigerian Comedy: Baba Sala. Illinois: Northwestern University. Viewed on 29 April 2016, http://www.hdi.net

Helliwell, J. F., Layard, R., \& Sachs, J. D. (2019). World Happiness Report. Retrieved from http://worldhappiness.report/

Ibrahim, A. T. (2019). Analysis of Corruption in the Nigerian Police Force. Journal Of Humanities And Social Science, 24(9), 1-5. https://doi.org/10.9790/0837-2409030105

Ijalana, E. (2010) 'I Have a Different History of Nigerian Comedy-GbengaAdeyinka'. Viewed on 29 April, 2016. http://www.nigeriafilms.com/news

Jagdale, R., Shirsat, V., \& Deshmukh, S. (2016). Sentiment Analysis of Events from Twitter Using Open Source Tool. International Journal of Computer Science and Mobile Computing, 5(April 2016), 475-485.

Kidd D. (2017). Popular Culture. obo in Sociology. doi: 10.1093/obo/9780199756384-0193

Koppel, M., \& Schler, J. (2006). The importance of neutral examples for learning sentiment. Computational Intelligence, 22(2), 100-109. https://doi.org/10.1111/j.14678640.2006.00276.x

Martin, E. (2011). Terrorism, humor, and American popular culture. Global Media and Communication, 7(3), 233-237. https://doi.org/10.1177/1742766511427495

Mendiburo-Seguel, A., Vargas, S., \& Rubio, A. (2017). Exposure to political disparagement humor and its impact on trust in politicians: How long does it last? Frontiers in Psychology, 8(DEC), 1-12. https://doi.org/10.3389/fpsyg.2017.02236

Mittal, A., \& Patidar, S. (2019). Sentiment Analysis on Twitter Data. Proceedings of the 2019 7th International Conference on Computer and Communications Management, 91-95. https://doi.org/10.1145/3348445.3348466

Nabi, R. L., Moyer-Gusé, E., \& Byrne, S. (2007). All Joking Aside: A Serious Investigation into the Persuasive Effect of Funny Social Issue Messages. Communication Monographs, 74(1), 29-54. https://doi.org/10.1080/03637750701196896

Obadare, E. (2009). The uses of ridicule: Humour, "infrapolitics" and civil society in Nigeria. African Affairs, 108(431), 241-261. https://doi.org/10.1093/afraf/adn086

Olonilua, A. (2011). 'Pillars of Stand-up Comedy'. Viewed on 29 April.2016. http://www.nigeriabestforum.com 
Olowojolu, O. (2017). Mid Term Report of President Muhammadu Buhari's Foreign Policy Vol 9. $\operatorname{Pg} 223$.

Osae-Brown, Funke (2015). Nigeria's Comedy Business Rakes in N50 Billion yearly, say Analysts. Business Day Online. Retrieved on May $25^{\text {th }}$ 2018, from http://www.businessdayonline.com/nigerias-comedy-business-rakes-in-n50bn-yearly-sayanalysts

Radda, S.I. (2010). A Theoretical Discourse on Social Problems. In Radda, S.I., Lawan, M. and Mukhtar, M. (Ed.), Issues in Nigeria's Social Problems (pp. 1-11). Kano, Nigeria: Benchmark

Saalman, I. (2014, September 10). Nigerian Police is the best in the world by Okey Bakassi [Video file]. Retrieved from https://youtu.be/gB7WFyx31CY

Shanthi, A., Wah, L. K., \& Lajium, D. (2015). Discourse Analysis as a Qualitative Approach to Study Information Sharing Practice in Malaysian Board Forums. International Journal on ELearning Practices, 2(November 2016), 159-169.

Tajfel, H., \& Billic, M. (1974). Familiarity and categorization in intergroup behavior. Journal of Experimental Social Psychology, 10(2), 159-170. https://doi.org/10.1016/00221031(74)90064-X

Taiwo, O. (2017). From Jagua To Ali Baba: Humour In Contemporary Nigeria. 3, $26-31$.

Tavory, I.. (2014). The Situations of Culture: Humor and the Limits of Measurability. Theory and Society. 43(3-4):275-89.

The Other News CTV. (n.d.). (955) The Other News CTV - YouTube. Retrieved May 22, 2020, from https://www.youtube.com/channel/UCfquiJA6_bKLo5m4CLqUphw/about

The Other News CTV. (2017, December 26). EXCLUSIVE: Charles Inojie Sits Down With Okey Bakassi | The Other News [Video]. YouTube. https://youtu.be/AgLhZrI6mck

The Other News CTV. (2018, October 26). Full Episode: The Other News | Oct. 252018 [Video]. YouTube. https://youtu.be/uFraC7HKtHc

The Other News CTV. (2018, February 16). HEADLINES: I Am Tired Says Boko Haram Leader Shekau | The Other News | Feb. 152018 [Video]. YouTube. https://youtu.be/Z82qUJY46Ho

The Other News CTV. (2018, March 23). Boko Haram Returns Dapchi Girls | Mar. 212018 [Video file]. YouTube. https://youtu.be/R5cRhXesWWk

Uwanamodo, D. (2019). Sociology of Laughter and Humor. The Rice Examiner, Rice University, (2, 1), 149-167. Retrieved from https://scholarship.rice.edu/bitstream/handle/1911/106095/examiner-2019-art08.pdf 
Welsh, T. (2015). New Nigerian President Faces Critical Challenges, US News \& World Report, available at http://www.usnews.com/news/articles/2015/05/29/new-nigerian-presidentfaces-boko-haram-corruptioneconomy

Zhang, L., Ghosh, R., Dekhil, M., Hsu, M., \& Liu, B. (2011). Combining lexicon-based and learning-based methods for twitter sentiment analysis. HP Laboratories Technical Report, 89.

Zillmann, D., \& Cantor, J. R. (1976/1996). A disposition theory of humour and mirth. In A. J. Chapman \& H. C. Foot (Eds.), Humor and laughter: Theory, research, and application. London: Wiley 